\title{
Persecution of Minorities in Algeria: What Fuels the Maltreatment?
}

\author{
Shaul M. Gabbay ${ }^{1}$ \\ ${ }^{1}$ Global Research Institute, Denver, Colorado, United States \\ Correspondence: Shaul M. Gabbay, Global Research Institute, Denver, Colorado, United States.
}

Received: April 19, 2021

Accepted: April 28, 2021

Available online: May 20, 2021

doi:10.11114/ijsss.v9i4.5241

URL: https://doi.org/10.11114/ijsss.v9i4.5241

\begin{abstract}
Algeria, the largest country in Africa, has nearly a uniform population. Arab Sunni Muslims comprise fully $99 \%$ of the 42 million strong-populace. Why, then, does its government grapple with fears of separatist movements from its own Sunni population? Further, why does it use suppression and persecution to hold down its meager minority populations that includes ethnic, cultural, religious, and linguistic denizens whose combined numbers total just $1 \%$ and who pose no serious threat to the powerful and often highly corrupt government and military force? The answer may lie in the rise of fundamentalist Islam, a movement that strives to make theocracy and Sharia law replace the current democratic government system. This balance of pleasing and thus containing the fundamentalist movement, which has consumed much of the Middle East and North Africa, has made its mark felt in Algeria and could threaten to destabilize one of the continent's most powerful nations.
\end{abstract}

Keywords: Algeria, separatist, Berber, Ahmadi, Islam

\section{Introduction}

\subsection{Government Persecution of Ethnic and Religious Minorities}

A cursory look at the ethnic and religious makeup of Algeria may lead one to believe that the nation of Algeria, with a population of 42 million citizens comprised of over 99\% Arab and 99\% Sunni Muslims, would have few occurrences of religious or ethnic persecution. Reality argues otherwise. Despite their overwhelming majority, government leaders, all of whom are Arab Sunni Muslims, act fearful of uprisings and struggle to co-exist with any group or anyone they perceive may have potential to upend the ironclad rule of the majority.

Increasingly in recent years the Algerian government has been castigated in multiple reports by international human rights groups for systemic discrimination against its religious, linguistic, and ethnic minorities. (US Commission on International Religious Freedom, 2021) Government persecution of minorities is evidenced by visible acts of religious intolerance and maltreatment, which manifest most frequently in police action targeting the Ahmadi community which often results in arrests and imprisonment. (Ahmad, 2017) This state-imposed oppression bodes poorly for other minorities in the country who have suffered subjugation in the past from governmental actors as well as religious authorities, tribal leaders, and among the general population.

For a decade starting in 2005, government persecution of minorities was mild and seemed to be transforming into tolerance and acceptance. A new era of concern has arisen since then as arrests and oppression of minorities has risen to troubling levels, indicating a new and expanding pattern. (Amnesty International, 2020)

This report will examine the various events, patterns, and threads of persecution woven throughout the government, religious leadership, and indeed, the general population. The experience of each minority group, including the afore-mentioned Ahmadis, will be examined to ascertain the current level of risk and abuse they endure.

\section{Algeria's Past Source of Ethnocentricity}

Situated on the northern seacoast of the African continent between the countries of Morocco on the West, and Tunisia and Libya on the East, Algeria is considered a gateway between Africa and Europe. With a 1600-kilometer long coastline, opportunities abound for European trade, for intercontinental travel, and - as native Algerians poignantly experienced in the past-for colonization. After three centuries under Ottoman rule, France seized the land in 1830, inculcating the Algerian people with French language and culture. French colonizers stayed for 115 years until World War II weakened France toward collapse, raising Algerians hopes for independence. By 1945 those hopes fueled 
pro-independence demonstrations during which thousands of Algerians were killed. Nine years later, the protests matured into serious battles, and the Algerian War of Independence fully erupted. For eight years brutal fighting continued, with approximately one million Algerians losing their lives. (Algerians claim 1.5 million of their own people died; France claims 400,000 Algerians died.) Ultimately, the Algerian people emerged victorious, and in1962 Algeria became an independent nation for the first time. (CIA Factbook, 2020)

\subsection{Language as an Imprint of Colonization}

As in most post-colonial countries, in Algeria the language of the colonizing power remains prominent in the culture. While Arabic was formally recognized as Algeria's official language when the Algerian constitution was adopted in 1963, French is also officially recognized, commonly spoken, and considered lingua franca, a second language used for trade and communication between different linguistic groups. In 2015, after years of campaigning by the indigenous Berber population who officially represent less than one-sixth of the total population, the Berber language (also known as Amazigh) was officially recognized as Algeria's third official language. (El Watan, 2017)

This up-leveling of Berber to an official state language came as a result of long-harbored and expressed complaints from the Berber population with ancient roots in the country that predate the ruling Arab population. (Technically, nearly all Algerians are Berber in origin, not Arab, yet most Algerians do not identify as such.) The group of Berbers who have maintained their Berber identity number about six million amidst a total population of 41 million, constituting $15 \%$. They live mainly, though not exclusively, in the mountainous region of Algeria known as Kabuli, located east of the capital city of Algiers.

Kabyles, as they are often referred, consider themselves as part of a broader group of native peoples that includes Moroccan Berbers, with whom they share a border, and the Tuareg, a nomadic tribe of Berbers who wander to different locations throughout the Saharan desert in the south of the country.

\subsection{Indigenous Berbers}

Berbers, also known as Amazighs, which means "the freeborn", are the indigenous inhabitants of Algeria. Berber culture, however, even within Algeria, is not homogenous. Rather, it is made up of four distinct groups: Kabyles, Shawiya, Mozabites, and Tuaregs. (Minority Rights Group International, 2020)

About half of the Berber-speaking population is concentrated in the mountainous areas of Kabylie. It is this educated group from which most contentious Berber issues in modern Algeria arise. Over time, the population has dwindled considerably as large numbers of Kabyles moved to cities in Algeria and France seeking a higher level of employment. (The Economist, 2014)

The second largest Berber group, the Shawiya, live primarily in the rugged mountains in eastern Algeria. A third, smaller Berber community, the Mozabites, live in north-central Algeria near the city of Ghardaia in the Sahara Desert. The Tuareg nomads of the southern Sahara make up the fourth and final group of Algerian Berbers. The 12,000 Tuareg live primarily near the mountainous plateau region of Ajjer and Ahagga, which is now a World Heritage Site due to its 15,000 ancient rock paintings and engravings as old as 12,000 years.

Geographical dispersion of Berber-speakers has hindered the cohesiveness of the community but has not destroyed their common identity. Kabyles are the most cosmopolitan and are more likely to speak French than other groups. Regardless of their lack of outward cohesiveness, native roots still bind Berbers, and their religious beliefs are largely, though not entirely, consistent among the four groups.

\subsection{Arabization}

This Berber bond was likely strengthened by the so-called "Arabization" of the country at the time of independence when Berber linguistic and cultural expressions, including Berber music and lectures by Berber professors, were outlawed. When the Berber population protested they were met with violent responses; thirty Berbers were killed by government troops and many more were arrested. Arab leaders feared a separatist movement could emerge among Berbers and took several steps to prevent any chance of that possibility occurring. Primarily they arrested and jailed Berber leaders in the decades following independence. Arab leaders completed the effort by passing the Arabization Bill in 1990 legislating that the entire government administration be Arab and added further constraints by legally mandating an all-Arab educational administration in 2000.

Tuaregs, the wandering Berbers who live in the Sahara desert, fought hard to remain independent and nomadic. Though they were aware of country borders and government, they saw themselves as nomads who belonged to a tribe but not a country. Their independence was contrary to the nationalist ideology that emerged following independence. An effort to constrain the roving lifestyle and independent nature of the Tuareg tribes created havoc during the decades following independence. Yet the Taureg were no match for the strength and power of the newly formed Algerian government. By 
the end of the first decade following independence, the Tuareg were largely assimilated into the Algerian system.

\section{Religion}

Just as language serves as both Algerian history lesson and modern-day chasm within in its population, religion constitutes a further source of division, as does the accompanying persecution experienced by many in the minority.

\subsection{Islam}

Islam first arrived in Algeria in the latter half of the 7th century, and by the 8th century nearly all Berbers had converted from Christianity. Today, fully $99 \%$ of the country is Sunni Muslim, including Berbers. Berbers, however, practice a far more relaxed form of Islam, which, together with their Berber language makes them suspect by the vast Arab majority who follow a far more dogmatic and rigid interpretation of Islam that requires precise adherence to Islamic principles and practices. Additionally, the vast majority also believe Arabic should be spoken exclusively because it is the language of the Quran, Islam's holy book. It is the rise of this Islamic fundamentalism creating the greatest rift in the country that has led to persecution of non-Muslims.

\subsection{Ahmadis}

Ahmadis are part of a Muslim movement, though they are not recognized as such by the Organization of Islamic Cooperation, of which Algeria is a member. Rather, they are seen as heretical. Their movement calls for non-violence and tolerance of all faiths. They follow the Quran, but do not believe Mohammed was the final prophet. Ahmadis follow the teachings of Ghulam Ahmad, an Indian Muslim born in Punjab in 1835. Ahmad believed himself to have been chosen by Allah to renew Islam, having found the practice of Islam to have "deteriorated to the point where divinely inspired reforms were needed." (BBC, 2010)

After years of persecution by orthodox Muslims in India, Ahmadis moved their headquarters to Pakistan in 1947. However, this did not result in any relief, as Ahmadis quickly became the most persecuted community in Pakistan based on their "heretical beliefs". After a law was enacted in Pakistan in 1974 deeming Ahmadis "non-Muslims", and preventing them from propagating their faith, they again moved their headquarters, this time to the non-Muslim United Kingdom. (BBC, 2010)

Since 1974, Ahmadis proselytized their way across Europe, Africa, America, and some parts of Asia. Today they number about 10 million, spread across 190 nations. They arrived en masse in Algeria via an Ahmadi satellite television station channel in 2007 and began accruing converts. For a decade Ahmadis worshipped as they wished in Algeria, and their practice flew largely under the radar of government forces and the general public. Then, in what seemed to be a sudden action, the government cracked down on Ahmadis in 2016. They arrested the president of the Ahmadi community, and arrested and prosecuted scores of Ahmadis, jailing many for over six months, accusing them of colluding with foreign powers. (Human Rights Watch, 2017) Ahmadi persecution in Algeria is representative of the norm in Muslim-dominant nations across Africa and Asia.

\subsection{Christians}

Before the arrival of Islam, Christians made up a 99\% majority in the region now known as Algeria. Today Christians in Algeria number fewer than 70,000. Their tiny percentage of the population, less than one-tenth of a percent, opens them up to routine pressure from their Muslim neighbors who are intolerant of their faith. Though technically protected by Algerian law to practice their faith, it remains illegal for Muslims to convert to Christianity. It is also difficult if not impossible to repair or build Christian churches. One source of discord is the fact that many Christian churches were built by the French, whose legacy is considered in a very negative light in Algeria. The process of restoring and maintaining places of worship built by a former oppressor is highly unpopular. Most Christians in Algeria today are not descendants of early 8th century Christians, but rather are children and grandchildren of French colonizers. In a country that harbors intense hatred and animosity for their former overlords who were responsible for the death of millions of Algerians, it is difficult for most to tolerate the reminders of the past in the form of their French, Christian neighbors.

There is no question that the greatest incidence of persecution among Algerian Christians falls on Muslims who convert to Christianity, an act considered a crime and an affront to Islam. (The North Africa Post, 2017) This act of conversion, known as apostasy, has occurred most often in the Kabylie region, which, as noted is an area already under persecution for ethnic reasons.

Despite legal punishment, persecution, and ostracization of Muslim converts to Christianity, recent years have seen a growing number of conversions across North Africa. A 2015 study by the United Nations estimated that 380,000 Muslims had converted to Christianity in the past decade. 
After decades of social and political discrimination, persecution, and the conversion of Jewish synagogues into mosques, there was complete silence about Jews who remained in Algeria. There was little evidence at all indicating any Jews still lived in Algeria, despite centuries of inhabitation and a long and thriving cultural presence.

However, beginning in 2005, the Algerian government tried to reduce discrimination against what turned out to be a hidden Jewish population of about 1000. The government established a Jewish association and passed a law to recognize freedom of religion. They also allowed a re-launching of Jewish pilgrimages to the most holy Jewish sites in North Africa. In 2014, Mohammed Eisa, the Minister of Religious Affairs, announced that the Algerian government would foster the reopening of Jewish synagogues. This did not transpire, however, with so few Jews left to attend. Today, the U.S State Department claims there are 2000 Jews living in Algeria, mostly in Algiers. Other estimates put the number closer to 50 .

The remaining Jews, whatever their number, are likely to be happily hidden amongst the Muslim populations. Accounts of collusion between Jews of Algeria and Israeli Jews against Muslim nations are based on pure conjecture. Such rumors create havoc for those Jews who remain.

\subsection{Bahai}

Unlike Jews and Christians whose history in Algeria dates back centuries, the Bahai faith arrived in Algeria as recently as the 1950's. The religion was entirely banned in 1968; still, about 3800 Bahai followers remain in Algeria today. Like the Jewish population, Bahais are nearly invisible as a distinct religion. Like Algeria's other minority religions, Bahai followers keep a very low profile and are often circumspect about their beliefs, living and worshipping within extremely small and tight knit communities.

\section{An Era of Persecution Resurges}

Following an unprecedented decade of tolerance for minorities in Algeria that began in 2005, the tide shifted back to suppression not long after the Arab Spring shook the foundation of North Africa in country after country, enveloping Algeria in the process.

Signs of revolution in North Africa began in Algeria and many neighboring countries in 2011 when protests erupted in Morocco, Tunisia, and Libya. This gave rise to Moroccan Berbers demanding recognition of their language and culture. Just months later, they were victorious. A new constitution, drafted in 2011, proclaimed Morocco's ethnic diversity and added Berber as an official language of Morocco, alongside Arabic.

On the Eastern flank of Algeria, Berbers in Libya had been battling President Qaddafi for decades as he had tried to destroy them and their culture from the landscape for decades. With the strength and momentum of the Arab Spring all around them, Libyan Berbers were the first to rise up against Qaddafi, forming militias that eventually helped oust him and win the civil war in that country.

In another neighboring country, Tunisia, Berbers also began agitating for cultural recognition of their language. Tiny numbers prevented them from any notable victories, however.

This movement for Berber recognition and dignity across much of North Africa awoke the fear and response among fundamentalist Muslims, who saw a challenge, however miniscule, to their overwhelming presence in Algeria. Despite the victory of the Berber language being added to the official national roster, the backlash was palpable and violent. In the end, however, Algeria's participation in the Arab Spring was relatively mild.

\subsection{Religious Violence Against Berbers}

The first well-documented occurrence of violence erupted after a long period of tension simmered between Algerian Arabs and one of the Berber communities, the Mozabites, after a Mozabite cemetery was desecrated. In a struggle over land, jobs, and houses, the two groups, who share neither ethnic, linguistic, nor religious backgrounds and beliefs, erupted in physical violence and over twenty-two people were killed in the fighting. Hundreds more were injured. While not a sign of government persecution, the eruption seemed to open up tensions throughout the country. In 2013, Algerian security forces arrested three young people who were eating in public during the holy month of Ramadan, a time when devout Muslims fast from dawn to dusk. The youth were Berbers from the Kabylie region who do not adhere to the stricter rules of Islam. In response to their arrest, three-hundred Kabylie Berbers staged an open lunch to "denounce the inquisition and persecution of citizens who, because of their beliefs, refuse to observe the fast." (France 24, 2014)

While many occurrences of arrests, harassment, and persecution against the Berber minority continue to this day, including the 2018 conviction and jail sentence of a Berber human rights activist for denouncing Islamo-Arab violence, the most severe and targeted persecution has centered on the tiny Ahmadiyya community.

As described earlier, Ahmadis are Muslims who believe strongly in the separation of church and state. They are growing 
in ranks as a reaction to Islamic fundamentalism, and many say they were having a crisis of faith as they witnessed the expansion of fundamentalist Islam which many blame on the radical Wahhabis in Saudi Arabia. Ahmadis believe in tolerance and acceptance of all religions, and practice non-violence. They further believe Mohammad was not the last prophet, but rather Ghulam Ahmad, an Indian Muslim who preached peace and coexistence was. Since 2016, when the persecution became visible, more than $20 \%$ of the 2000 Ahmadis in Algeria have been arrested and jailed. As of December 2020, nearly 300 were awaiting trial, some from prison. Senior government officials have at times claimed that Ahmadis represent a threat to the majority Sunni Muslim faith () (Human Rights Watch, 2018) and accused them of collusion with foreign powers.

According to Mohamed Fali, president of the Algeria's Ahmadiyya community, authorities have arrested and tried Ahmadis under one or more of the following charges: denigrating the dogma or precepts of Islam; participation in an unauthorized association; collecting donations without a license; and possession and distribution of documents from foreign sources that endanger national security. At least 20 have faced a charge of practicing religion in an unauthorized place of worship under Algeria's 2006 law governing non-Muslim religions even though Ahmadis consider themselves Muslim. (Human Rights Watch, 2018)

Mohamed Fali himself was arrested in August of 2017 on the basis of an in abstentia judgment six months earlier that had sentenced him to 3 months in prison. According to Human Rights Watch, who's staff have interviewed scores of persecuted Ahmadis, authorities have denied them the right to form an association. They demolished a building in Larbaa where Ahmadis worshipped and gathered. In an interview with Human Rights Watch, Ahmadis complained that Algerian authorities "confiscate religious books, documents about the Ahmadiyya faith, computers, identity cards, and passports during searches." (Human Rights Watch, 2018)

\subsection{Religious Violence Against Christians}

For Algerian Christians, the pressure comes largely from fundamentalist Muslims in the community who are intolerant of having Christians live among them. However, the restrictions are imposed by both the state and society. Laws regulate all non-Muslim worship; they ban conversion to Christianity, and they prohibit so-called blasphemy, (any form of criticizing Islam, Mohammed, or a number of other Islamic traditions), all of which makes proselytizing and public expression of the Christian faith dangerous. In fact, something as mild as a casual conversation between friends and family members regarding faith can be grounds for blasphemy charges. (North Africa Post, 2017)

The penalties for all these restrictions can be draconian. For example, in July of 2016, a Christian Algerian man named Sliming Bouhafs was arrested for "insulting Islam". He was sentenced to prison, where he remains today. Not only is the penalty severe, but he must also endure extreme harassment from fellow prisoners.

Other examples of Christian persecution include being forced to bury relatives according to Islamic religious rites, as opposed to Christian burial rites, which can be deeply disturbing to religious family members at a time of sorrow.

Further, in the last few years, several Christian churches have been ordered to cease all religious activities if their followers include members with Muslim backgrounds. Christians in all parts of the country also suffer harassment and discrimination at the hands of family and neighbors who pressure or force them to adhere to Islamic norms and rites surrounding marriage, burial and other life events.

\subsection{Religious Violence Against Jews}

The conflation of Zionism, a modern political movement that thrives in Israel, with ancient religious Judaism, is the greatest problem facing Algerian Jews today. Accusations of spying and aligning with the enemy, Israel, are the primary issue that elicit Jewish persecution in modern day Algeria.

In 2015, Algeria's Minister of Religious Affairs suggested reopening 25 synagogues which had been closed in the late 1990's. The idea was panned as Muslim protests won the day. It seemed a moot point, however, as nearly all Jews in Algeria hide their Jewish identity. One Algerian journalist wrote: "Today, Jews are like ghosts in Algeria; we hear about them living among us, but we never see them." Some say Jews still live in Algeria under strict surveillance, but most Algerians are confused, wondering if a Jewish-Algerian community still exists, and if so, whether it is safe to speak about it. Many suspect that the community does exists, but fear that this is a matter of state security about which they should not comment." (Souames, 2015)

The Arab-Israeli conflict has undermined hopes for any resurgence of a healthy Jewish community in Algeria. Unless and until that decades-long conflict is resolved, it is likely that Jews in Algeria, as in most Arab countries, will cease to live and worship openly.

\section{Conclusion}

In recent years, a rising tide of concern regarding Algeria's treatment of its minority populations by Western countries, 
including the United States, the UK, France, and others, has highlighted a growing concern for minorities of all kinds: cultural, ethnic, religious, and linguistic. A preponderance of negative reporting by the world press, by human rights NGO's, by churches, and by other religious groups has highlighted the very real and growing concern that freedom and life itself is tenuous for tens of thousands of individuals who call Algeria home.

The current direction of Algeria's government must be closely observed, and the treatment of its minorities must be monitored to ensure their freedom and safety. The trajectory of Algeria's religious dominance shows an adherence to the principles of fundamentalist Islam, and a rejection of separation and church and state. As long this government operates guided by this principle, care must be taken to protect those individuals and communities who the government perceives to be a risk and a threat to its power.

\section{References}

Ahmad, U. (2017, September 15). In Persecution of Ahmadis, Evidence of Growing Religious Intolerance in Algeria. London, England.

Amnesty International. (2020, August 15). Algeria 2020. Retrieved from Amnesty International: https://www.amnesty.org/en/countries/middle-east-and-north-africa/algeria/report-algeria/

BBC. (2010, May 10). Who Are the Ahmadi. Retrieved from BBC News: http://news.bbc.co.uk/2/hi/south_asia/8711026.stm

CIA Factbook. (2020). Algeria. Retrieved from The World Factbook: https://www.cia.gov/the-world-factbook/countries/algeria/

El Watan. (2017, January 3). In Algeria, Berbers Fight for Equal Amazigh-Arabic Language. El Watan Algerian French Language Periodical.

France 24. (2014, March 18). 22 People Killed in Ethnic Clashes between Arab and Amazigh. Ghardaia, Algeria.

Human Rights Watch. (2017). Algeria: Stop Persecuting a Religious Minority. New York City: Human Rights Watch . Retrieved from Human Rights Watch:

https://www.hrw.org/news/2017/09/04/algeria-stop-persecuting-religious-minority

Human Rights Watch. (2018, January 22). Algeria: New Trials Shaek Ahmadi Minority. Beirut, Lebanon.

Minority Rights Group International. (2020, August 12). Algeria: Berbers. Retrieved from Minority Rights Group: https://minorityrights.org/minorities/berbers/

North Africa Post. (2017). Surrounded by Hostility, Algeria's Christians Struggle to Meet Day-to-Day Needs. Algiers: Persecution: International Christian Concern.

Souames, F. (2015). Home, for Algeria's Jews, is Elsewhere. Retrieved from Open Global Rights: https://www.openglobalrights.org/home-for-algerias-jews-is-elsewhere/

The Economist. (2014, February 26). The Middle East | Pomegranite. Mixed Fortunes: The North African People are Claiming their Rights.

The North Africa Post. (2017, September 18). The Plight of Minorities in Algeria. Algiers, Algeria.

US Commission on International Religious Freedom. (2021). USCIRF Troubled by Escalating Persecution of Ahmadi Muslims in Algeria. Washington, D.C.: United States Commission on International Religious Freedeom.

\section{Copyrights}

Copyright for this article is retained by the author(s), with first publication rights granted to the journal.

This is an open-access article distributed under the terms and conditions of the Creative Commons Attribution license which permits unrestricted use, distribution, and reproduction in any medium, provided the original work is properly cited. 